Submitted to Journal of Geochimica

UCRL-20157

et Cosmochimica Acta

Preprint $\mathrm{S}$.

HYDROCARBON CONSTITUENTS OF ICELAND

LEAF FOSSIL

Jerry Han and Melvin Calvin

October 1970

AEC Contract No. W-7405-eng-48

TWO-WEEK LOAN COPY

This is a Library Circulating Copy

which may be borrowed for tho weeks.

For a personal retention compr. call

Tech. Hnfo. Division. Ext. 5545

LAWRENCE RADIATION LABORATORY
UNIVERSITY OF CALIFORNIA BERELEE 


\section{Hydrocarbon Constituents of Iceland Leaf Fossil}

Jerry Han and Melvin Calvin

Departiment of Chemistry, Space Sciences Laboratory and Laboratory of Cheliical Biodynanics, University of California Berkeley, California 94720

Abstract-.-The hydrocarbon content of leaf fossils from Iceland has been investigated by gas chromatography-mass spectrometry. The distribution patterns of normal hydrocarbons, branched hydrocarbons, and cyclic hydrocarbons are compared to those of present-day living organisms. The diagenetic pathways of these hydrocarbons are discussed.

\section{Introduction}

Organic molecules derived from dead organisms as a result of diagenesis are important in organic geochemistry. Those molecules result from three processes: anaerobic bacterial transformation, thermal decomposition or thermal cracking, and condensation. It is suggested that, given sufficient time, all organic and biological matter is eventually reduced either to condensates resembling kerogen and graphite, or to thermostable paraffinic hydrocarbons. Temperature and pressure are the major factors for the degradation and condensation reactions.

The association of organic matter with sediments has been studied for the past decade. Several classes of organic compounds have been reported, such as alkanes (Oro' 1965, Bray 1965, Johns 1966, and Han 1969a), fatty acids (Kvenvolden 1967, Hoering 1964, and Van Hoeven 1969), anino acids (Schopf 1968) and porpliyrins (Meinschein 1965, and Hodgson 1968). The occurrence of matter other than hydrocarbons may serve as an indication that diagensis of these molecules has 
not reached its final stages. The hydrocarbons, which are the stable biologica? markers, have probably received the most attention. Some firin correlation of hydrocarbons between the present-day living organisms and the fossils permits a systematic search for chemical evidence of diagenesis over long periods of geological time.

A large slab of leaf fossil (Fig. 1) from Iceland was received from Dr. J.A. Wolfe, U.S. Geological Survey. It is found that the leaf fossils are piled very closely together and sandstones scattered around the slab. The sample is collected from Brjanslaekur, northwest penisula, Iceland. The fossil is on the middle of a number of horizons in the plateau (a Tertiary flora of Hoffell and Tjörnes type, ranging perhaps from Upper Miocene to Upper Pliocene) $10 \sim 15 \times 10^{6}$ years, a mild-temperature climate is indicated (Pflug, 1959). The fossils seem to belong to willows, birch, and alder (T. Einarsson, 1963), which are embedded in clay and consist of numerous leaves and a small part of wood chips, apparentiy carried by a sluggish river and buried in its muddy bottom.

\section{Experinental}

After the outside surface of the rock was removed by a clean watercooled diamond saw, the larger rock segment was wrapped in alumimum foil and fragmented using a hammer. The chips were collected and washed in a flask containing a mixture of benzene and methanol. The chips were dried in an oven and pulverized by a disc mill. The pulverized powder was less than 120 mesh in size. The powder was extracted three times with $3: 1$ benzene/methanol using an ultrasonic vibrator. After centrifugation, the supernatant solution 
Was renoved, yielding the "total cxiract."

An alumina column ( $3 \mathrm{ft} \times 0.5 \mathrm{in.}$ ) was prepared from $150 \mathrm{~g}$ of aciivated ncutral aluminum oxide and washed with $200 \mathrm{ml}$ of $n$-heptanc. The total extract was mixed with $2 \mathrm{~g}$ aluminum oxide and transferred to the top of the column, after which it was eluted with 150ml of n-heptane. The "total hydrocarbons" represented in this fraction show minimal U.v. absorption at $270 m_{u}$. The normal alkanes were separated from branched-cyclic hydrocarbons with a $5 \AA$ molecular sieve (0'Connor et al., 1962). A 50:1 weight ratio of sieve to sample was used. The sieve and sample were placed in a round-bottomed flask and refluxed in dry isooctane for two days. After centrifugation, the solution containing the branched-cyclic fraction was removed. The sieve was thoroughly extracted with hot isooctane for several hours and the washings were added to the branched-cyclic fraction. The isooctane-washed sieve, which contained the normal. paraffins, was treated with a mixture of $20 \% \mathrm{HF}$ and benzene for one hour. After separation of the layers, the benzene solution of $n$-alkanes was filtered, and the solvent was evaporated.

Al7 fractions were analyzed on Aerograph Model 204 gas chromatograph equipped with a capillary column which was coated in this laboratory. The gas chromatograms of "total hydrocarbons," "branched-cyclic hydrocarbons" and "normal hydrocarbons" are shown in Figures 2, $3 A$, and $3 B$, respectively. Coinjections of pristane and phytane were made, the locations of these stands coincide with the peaks labeled on Figure $3 \mathrm{~A}$.

All mass spectra were taken using a combination of an Aerograph 204 gas chromatograph and an A.E.I. MS-12 mass spectrometer. The gas chromatographic 
oven temperature was programned from $90^{\circ}$ to $300^{\circ} \mathrm{C}$ at $2^{\circ} \mathrm{C} / \mathrm{min}$ with a helium flow rate of $2.5 \mathrm{ml} / \mathrm{min}$. The effluent from the capillary column was split into two parts, $1.5 \mathrm{ml} / \mathrm{min}$ going to the flame ionization detector and $1 \mathrm{ml} / \mathrm{min}$ going through a $1 \mathrm{ft} \times 0.002 \mathrm{in}$. heated stainless steel tube at $220^{\circ} \mathrm{C}$ to the ion source of the mass spectrometer. These spectra were determined at an ionizing voltage of $70 \mathrm{eV}$ and an ionizing current of $50 \mu \mathrm{A}$. The temperature of the ion source was $200^{\circ} \mathrm{C}$. Each spectrum was scanned in three seconds. The spectra were recorded on an oscillograph recorder.

\section{Results}

The weight of the total heptane eluate contained $85 \mathrm{ppm}$ of the sample weight. The n-alkanes, representing $50 \mathrm{ppm}$ of leaf fossil, range from $\mathrm{C}_{12}$ to $C_{29}$ (Fig. 3B). Identifications were made by mass spectral analyses and by coinjections with standard samples on a capillary gas chromatograph. There was no significant predominance of odd over even carbon numbered $n$-paraffins in the range from $C_{12}$ to $C_{19}$. However, the ratio of odd over even carbon-numbered alkanes increased for higher molecular weights, and it showed a marked odd/even preference with $n-C_{27}$ and $n-C_{29}$ the most abundant hydrocarbons.

The mass spectra of the major components in Fig. $3 A^{\prime}$ 's peaks, a,b,c and d are shown in Fig. $4 A, B, C$ and $D$, respectively. Their molecular weights and formulas are listed in Table I. 


\section{Table I}

$\begin{array}{cccc}\text { Compound } & \text { Hol. Wt. } & \text { Formula } & \\ \text { A } & 218 & \mathrm{C}_{18} \mathrm{H}_{32} & \text { tricyclic terpone } \\ B & 262 & \mathrm{C}_{19} \mathrm{H}_{34} & \text { tricyclic terpanc } \\ \text { C } & 328 & \mathrm{C}_{24} \mathrm{H}_{40} & \begin{array}{c}\text { two degree of unsat. } \\ \text { tricyclic terpane }\end{array} \\ 0 & 318 & \mathrm{C}_{23} \mathrm{H}_{42} & \text { tricyclic terpane }\end{array}$

It has been impossible to assign unequivocal structures to these compounds on the basis of mass spectrometry alone. The mass spectrum suggests that these substances are not related to any of the common cyclic hydrocarbon structures such as steranes, triterpanes, and tetraterpanes that have been characterized in sediments (Burlingame et al., 1965, Murphy et al., 1967, Henderson et al., 1969) and may have the structures of a tricyclic series related to deterpanes, and triterpanes. We are investigating the structures of these compounds in order to establish them unequivocally. We already know from their behavior on silver nitrate thin layer chromatography (Morris, 1962) that $A$, B, and D do not contain any double bonds, while $\mathrm{C}$ does. From the molecular weight of C, we deduce two degrees of unsaturation.

Since the leaf fossils were identified as willows, birch, and alder, we were interested in comparing the hydrocarbon constituents between modern day living organism and the fossils. We examined five species of leaves: the Willows Salix Spp. (with long, slender, tapering foliage with prominent basal stipules, flowers in catkins, and cottony winged seeds); Salix matsudana (its rounded crown of twisted, spiralling branches may reach $30^{\prime}$ in height and $20^{\prime}$ in diameter. The narrow $3^{\prime \prime}$ leaves have sharply toothed margins, are 
whitish on the underside and curled or twisted); the birch Eetula panyrifora. (the ovate leaf blades on slightiy hairy stems, are 4" long by half as broad witi doubly serrated margins and flattened or heart-shaped bases); Betula verrucosa (European white birch); and the alder, Ainus oregona (its 3 " to 6" leaves are coarsely toothed and have rolled edges.) The outline of the extraction sheme was described elsewhere (Han et al., 1968). Table II shows the relative abundance of the individual hydrocarbons in total heptane eluate (given as $\%$ of total hydrocarbon present).

Table II

$$
n-c_{23} \quad n-c_{25} \quad n-c_{27} \quad n-c_{29} \quad n-C_{31}
$$

Salix spp.

$-$

Salix matsudana

Betula papyrifera

Betula verrucosa -

$\begin{array}{llllll}\text { Alnus oregona } & 1 & 2 & 50 & 42 & 4\end{array}$

The analysis of the heptane fraction, revealed the presence of a series of odd numbered normal hydrocarbons, from $n-C_{23}$ to $n-C_{31}$ with the $n-C_{27}$ and $n-C_{29}$ hydrocarbon predominant for each species and the absence of the aformentioned tricyclic hydrocarbons. In addition, neither the even numbered hydrocarbons nor the lower molecular weight alkanes have been found in significant amount. In each case the weight of total heptane eluate obtained $0.02-0.05 \%$ of the dry cell weight. 


\section{Discussion}

Normal paraffins are among the most stable of all biogenic orgaric compounds and are thought to be diagnosic of biologically produced organic matter which can be derived from the decarboxylation of fatty acids. The $n-C_{27}$ and $n-C_{29}$ are the dominant hydrocarbons in the present-day leaves of willows, birch, and alder. The Iceland leaf fossils have two peak maxima in the normal alkane fraction, one at $n-C_{17}$ another one at $n-C_{27}$ and $n-C_{29}$. It appears that the high molecular weight of odd-numbered paraffins, $n-c_{27}$ and $n-C_{29}$ are contributed by higher plants. These materials may well be preserved over long periods of geological time without changing their structure.

The distribution pattern of normal alkanes in higher organized plants has been always characterized by the occurrence of higher hydrocarbons (from $C_{23}$ to $C_{35}$, Eglinton et al., 1963) with clearly predominating odd-numbered homologues. This view, based especially on the work of Stransky and co-workers (1966, 1969), has been commonly accepted to be universally valid. Some of the earlier microorganism studied (Han et al., 1969b) contain clearly more lower alkanes (lower than $n-C_{23}$ ). The $n-C_{17}$ hydrocarbon is predominant in algae, and its dominance is decreased in photosynthetic bacteria. Normal heptadecane intensity is not outstanding in non-photosynthetic bacteria and is generally absent in higher plants. In all cases, the odd over even carbonnumbered n-paraffins is approximately 1.0 in aerobic and anaerobic bacteria, while the value is 1.0 to 5.0 in algae when the predominant component $n-C_{77}$ is excluded. 
The gas chromatogram of the lower part of normal alkane fraction of leaf fossil (Fig. 3B) shows a smooth distribution with a maximuri at $n-C_{17}$. This result together with $n-C_{27}$ and $n-C_{29}$ alkanes found in higher range, could be interpreted that the higher plants (willows, birch, and alder) and microorganisms (algae and bacteria) have played equally important roles in normal hydrocarbon production in this fossilized rock.

Isoprenoid hydrocarbons are absent in algae and willows, etc., but the chlorophylis are present in algae and leaves. Isoprenoid hydrocarbons are considered to be the diagenetic products of the phytyl side chain of the chlorophyll molecule (Bendoraitis et al., 1962, 1963). It is suggested that the initial degradation process has to take place by attack at the alcohol end. This could then be followed by reducing and thermal cracking mechanisms to give the $C_{15}$ to $C_{20}$ isoprenoid hydrocarbons found in the short period of geological time.

Tricyclic diterpenes have been found in present-day biological source materials, particularly the resin acids and gibberillins. The present hydrocarbons must surely have a biological origin for precursor. It would seem reasonable to assume that they represent the products of diagenetic a) teration of tricyclic terpenoids in this Iceland fossil. As such, this series of new biological markers seems to be significant, and an understanding of their detailed structure and origin could further illuminate the problem of biochemical and plant evolution and also increase our knowledge of diagenetic process in sediments. 
Acknowledgements---We thank Dr. J.A. Wolfe, U.S. Geological survey for supplies of Iceland Leaf Fossils. The work described was supported in part by the National Aeronautics and Space Administration Grant Ho. 05003-003 and in part by the U.S. Atomic Energy Commission. 
Rererences

BENDORAITIS J.G., BROWN B.L. and HEPNER L.S. (1963) Isolation and icicritification of isoprenoids in petroleum. Horld Petroleum Congress, Frankfort/iain, Geriany, June $19-26$.

BENDORAITIS J.G., BROIN G.L. and HEPNER L.S. (1962) Isoprenoid hycirocarbons in petrolcum. Anal. Chem. 34, 49-53.

BRAY E.E., and EVANS E.D. (1965) Hydrocarbons in non-reservoir-rock source beds, Bull. Arl. Asso. Petro. Geo. 49, 248-25\%.

BURLIKGAME A.L., HAUG P., BELSKY T., and CALVIN H., (1965) Occurrence of biogenic steranes and pentacyclic triterpanes in an Eocene shale and in an early precambrian shale, Proc. Nat7. Acad. Sci. 54, 1406-1412.

EGLINTON G. and HAidLTON R.J. (1963) The Distribution of Alkanes Chenical Plant Taxonomy Ed. Swain T., Acad. Press, London and Hew York 187-217.

EINARSSON T. (1963) Some chapters of the Tertiary History of Iceland, North Atlantic Biota and Their Mistory, Editors, A. Love and D. Love, The Macirillan Co., N.Y.

HAN J. and CALVIN M. (1969a) Occurrence of fatty acids and aliphatic Hydrocarbons in a 3.4 billion-year-old sediment, Nature 224, 576-577.

HAN J. and CALVIN If. (1969b) Hydrocarbon distribution of algae and bacteria, and microbiological activity in sediments, Proc. Nat1. Acad. Sci. 64, 436-483.

HAN J., MCCARTHY E.D., VanHOEVEN, CALVIN M., and BRAOLEY W.H. (1968) Organic Geochemical Studies II $A$ prelininary report on the distribution of aliphatic hydrocarbons in algae, in bacteria, and in a recent lake sediment, liatl. Acad. Sci. 59, 29-33.

HENOERSON W., WOLLRAB V., and EGLINTON G. (1969) Identification of Steranes and Triterpanes from a geological Source by Capillary Gas Liquid Chromatography and Mass Spectrometry, Advances in Organic Geochemistry 1903, (I. Havenaar and P.A. Schenck, Eds.) Pergamon - Vieweg, Braunschweig, 181-207. 
HODGSON G.W., HITCHON B., TAGUCHI K., BAKER B.L. and PEAKE E. (1968) Geochemistry of porphyrins, chlorins and polycyclic aromatics in solids, sediments and sedimentary rocks. Geochim. Cosmochim. Acta 32, 737-772.

HOERING T.C. and ABELSON P.H. (1964) Chemicals from Nonesuch Shale, Carnegie Inst., Wash. Y.B. 63, 262-269.

JOHNS R.B., BELSKY T., MCCARTHY E.D., BURLINGAliE A.L., HAUG P., SCHNOES H.K., RICHTER W., and CALVIN M. (1966) The organic geochemistry of ancient sediments Part II, Geochim. et Cosmochim. Acta 30, 1191-1222.

KVENVOLDEN K.A. (1967) Normal fatty acids in sediments, J. Am. 0il Chem. Soc. $44,628-636$.

MEINSCHEIN W.G., BARGHOORN E.S. and SCHOPF J.W. (1965) Paleobiology of a Precambrian shale. Science 148, 461-472.

MORRIS, L.J. (1962) Separation of Higher Fatty Acids Isomers and Vinylogues by Thin-Layer Chromatography. Chemistry \& Industry 1238.

MURPHY M.T.J., MCCORMICK A., and EGLINTON G. (1967) Perhydro-B-caioten in the Green River Shale, Science 157, 1040-1042.

O'CONNOR J.G., BURROW F.H. and NORRIS M.S. (1962) Determination of Normal Paraffins in $\mathrm{C}_{20}$ to $\mathrm{C}_{32}$ paraffin waxes by molecular sieve adsorption. Molecular weight distribution by gas-liquid chromatography. Anal. Chem. 34, 82-85. ORÓ J., NOONER D.W., ZLATKIS A., WIKSTRÖM S.A. and BARGHOORN E.S. (1965) Hydrocarbons of biological origin in sediments about 2 billion years old, Science $148,77-79$.

PFLUG, H.D. (1959) Sporenbilder aus Island und ihre stratigraphische deutung. Neues Jahrb. Geol. Paläontolog. Abh. 107, 141-172.

SCHOPF J.W., KVENVOLDEN K.A. and BARGHOORN E.S. (1968) Anino acids in Precambrian sediments: an assay. Proc. Nat. Acad. Sci. 59, 639-646.

STRANSKY K., STREIBL M., and HEROUT V. (1966) On natural waxes VI. Distribution of wax hydrocarbons in plants at different evolutionary levels, Coil. Czeh.

Chem. Commun. 32, 3213-3220. 
STRMNSKY K. and STREIBL M. (1969) On natural vaxes XII Coinposition of hydrocarbons in morphologically different plant parts, Coll. Czeh. Chem. Comiun. $31,103-11 \%$

VanHOEVEN H., MAXWELL J.R. and CALVIN M. (1969) Fatty acids and hydrocarbons as evidence of life processes in ancient sediments and crude oil, Geochira. et Cosmochim. Acta 33,877-887. 
Figure 1 A small slab of Iceland leaf fossil, $20 \mathrm{~cm}$ long and $12 \mathrm{~cm}$ wide. 


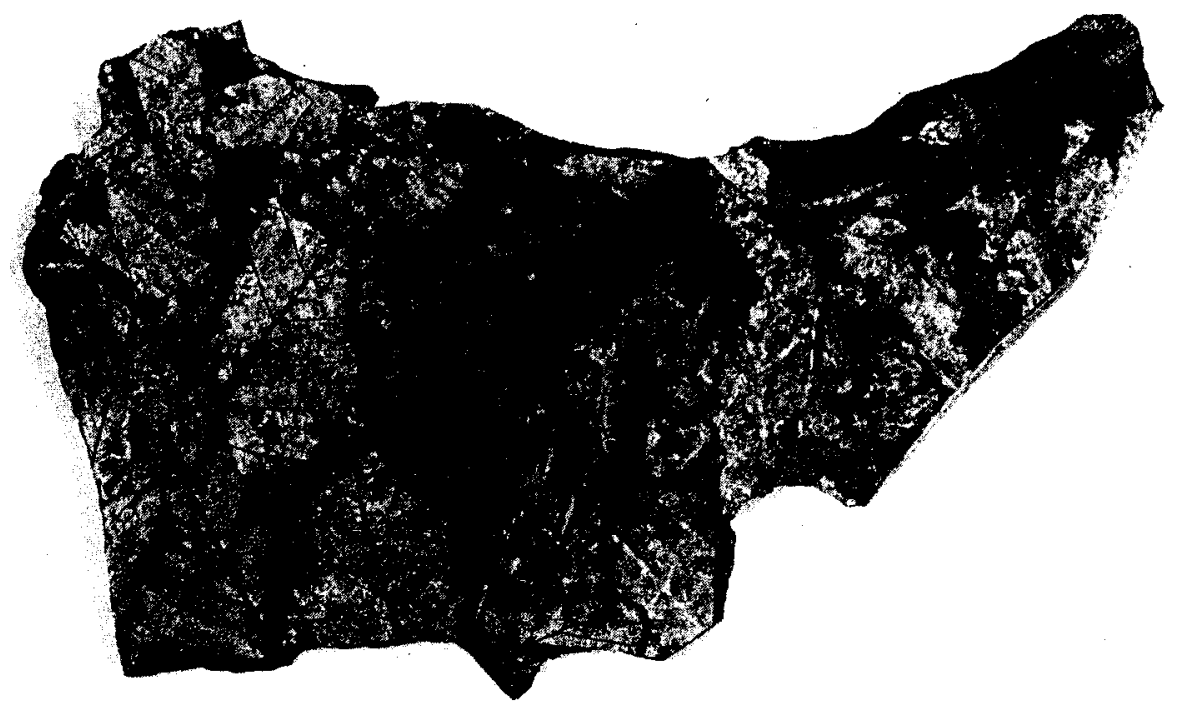

XBB 698-5355

Fig. 1 
Fig. 2 Gas chromatomaphic separation of total aliphatic hydrocarions of Iceland leaf fossil. A $100 \mathrm{ft}$. 0.01 in. I.D. stainiciss stécl column coated with Apiezon L was used. Helium pressure, 20 psi; flow rate $2.5 \mathrm{mi} / \mathrm{min}$; no split. An aerograph 204 apparatus equipped with a flame ionization detector was used. Temperature was programmed at $2^{\circ} \mathrm{C} / \mathrm{min}$. from $90^{\circ} \mathrm{C}$ to $290^{\circ} \mathrm{C}$ and was held isothermally at $290^{\circ} \mathrm{C}$. 


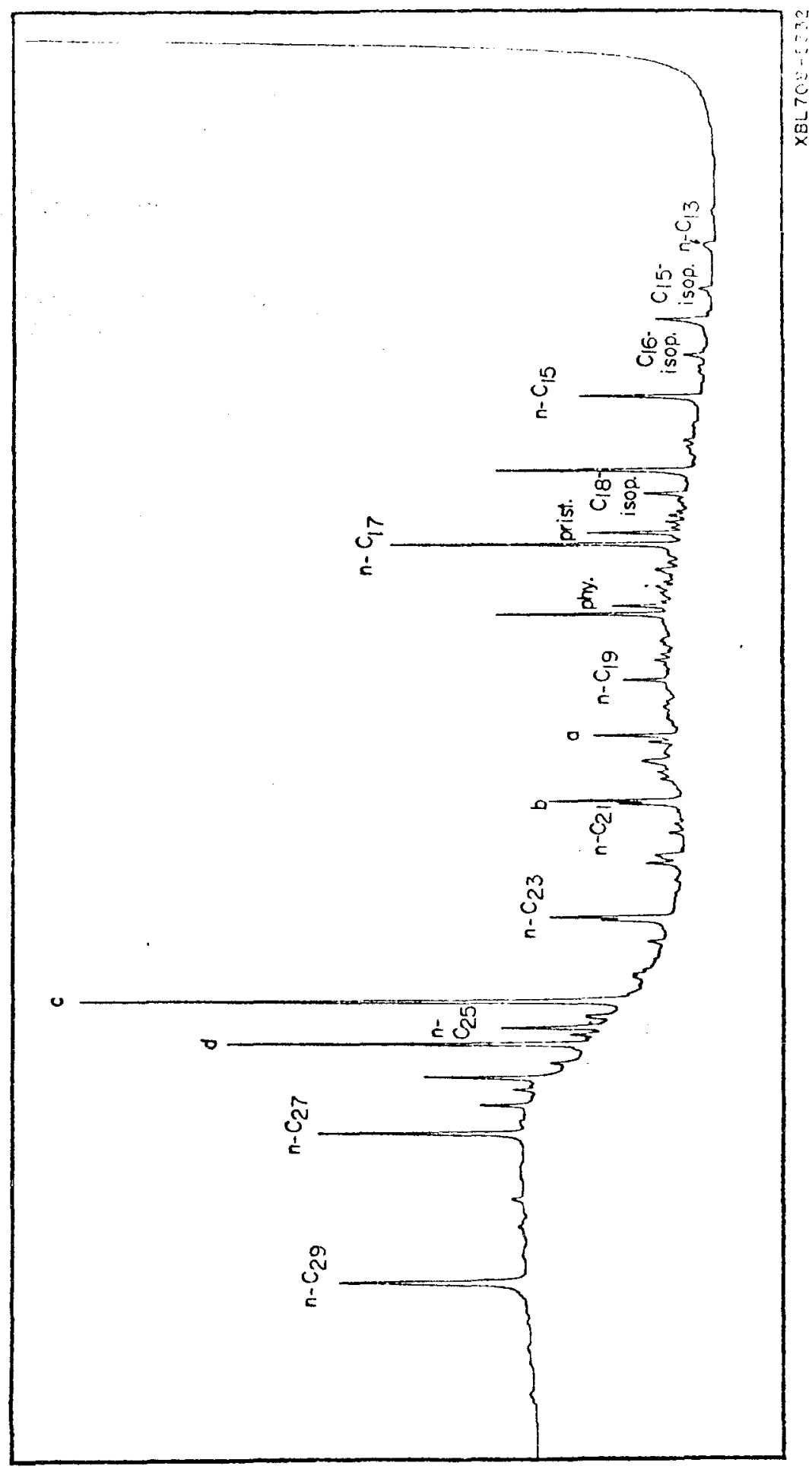


Fig. 3 The top figure (A) shows the gas chromatogram of branched and cyclic hydrocarbon fraction and the bottom figure shows the normal hydrocarbon fraction from Iceland leaf fossil. All the conditions are described in fig. 2 except the temperature was programmed from $90^{\circ} \mathrm{C}$ to $270^{\circ} \mathrm{C}$ and was heid isothermally at $270^{\circ} \mathrm{C}$. 


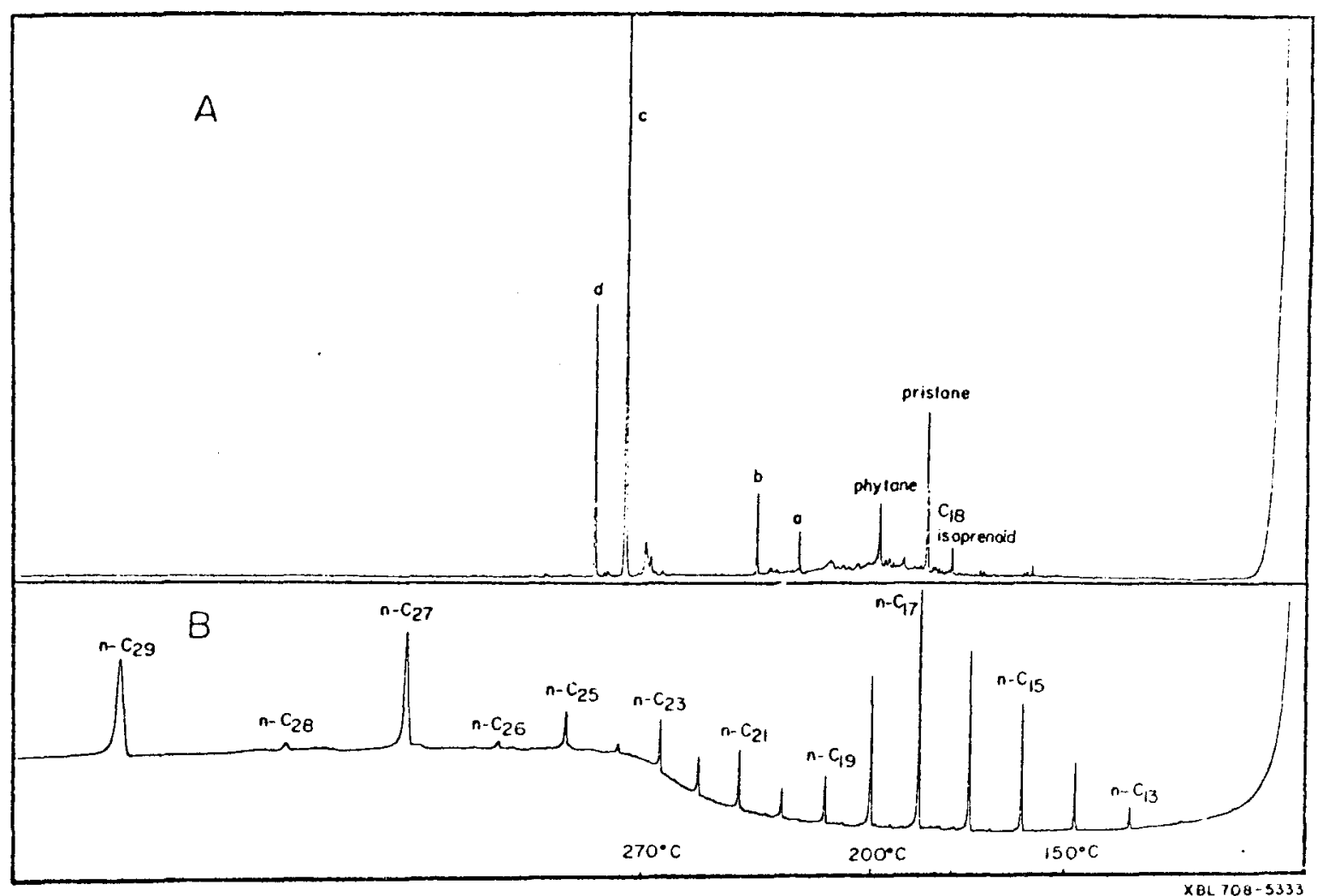


Fig. 4 The mass spectra of the major components in fig. 3A Spectra $A, B, C, \&$, are corresponded to peak $a, b, c$, and $d$, respectivcly. They were taken as the components were eluted from a $100 \mathrm{ft}$. $x 0.01 \mathrm{in.}$ I.D. Apiezon L capillary gas chromatographic column. The compounds were ionized by electron impact at $70 \mathrm{ev}$, the ion source tomperature at $200^{\circ} \mathrm{C}$, and an ionizing current of $50 \mu \mathrm{A}$. Each peak was scanned within the range of 10-600 mass units in $3 \mathrm{sec}$. on an A.E.I. MS-12 mass spectrometer. 

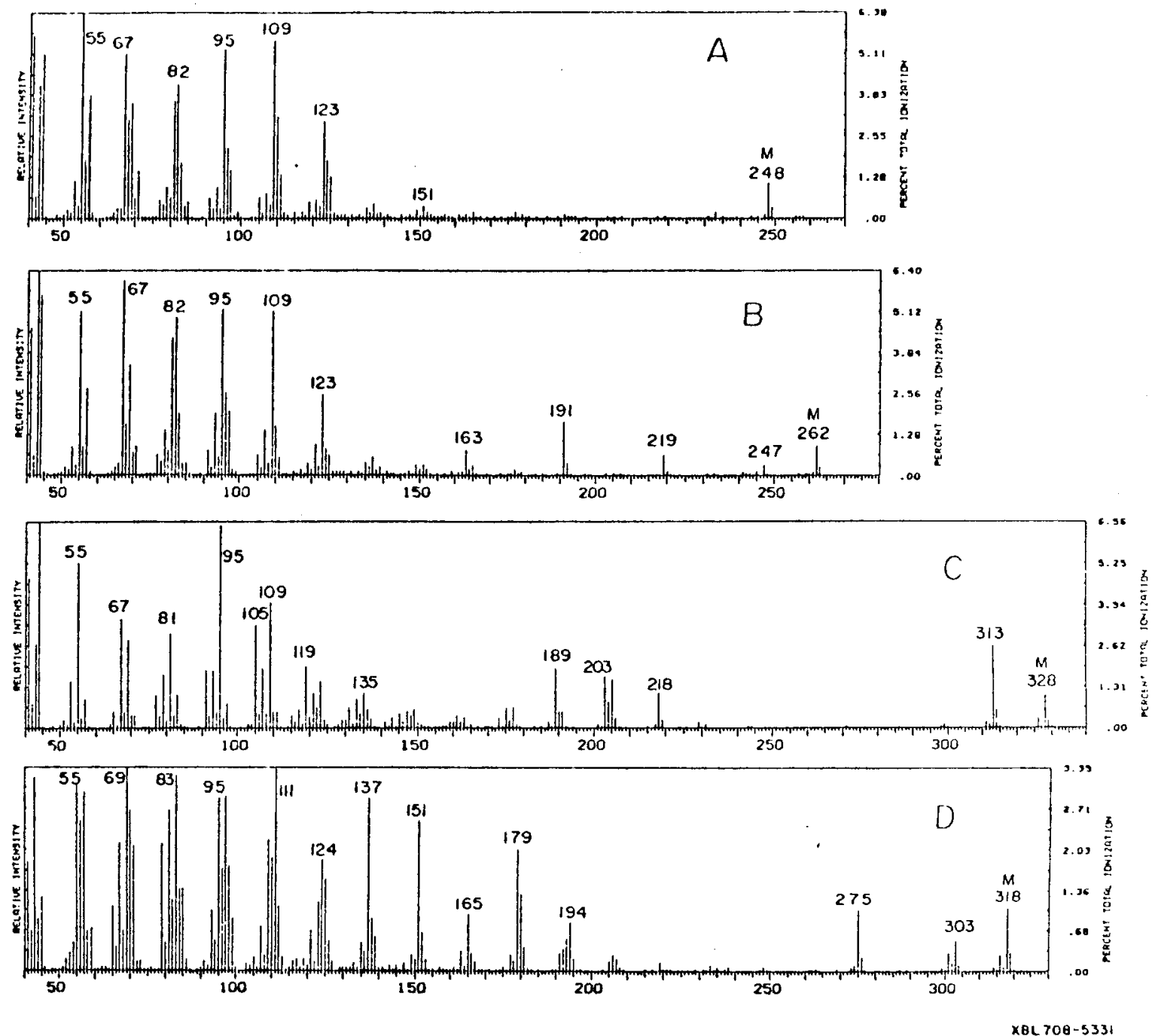